\title{
Diet and feeding of the nassariid Buccinanops cochlidium from northern Patagonia, Argentina
}

\author{
Andres Averbuj ${ }^{1, *}$, Gabriela Palomo ${ }^{2}$, Martín I. Brogger ${ }^{2}$, Pablo E. Penchaszadeh ${ }^{2}$ \\ ${ }^{1}$ LARBIM Centro Nacional Patagónico-CONICET, Puerto Madryn U9120ACD, Chubut, Argentina \\ ${ }^{2}$ Museo Argentino de Ciencias Naturales Bernardino Rivadavia-CONICET, C1405DJR, Buenos Aires, Argentina
}

\begin{abstract}
The Nassariidae are considered to be carrion feeders. Nevertheless, the feeding habits of this family also include herbivory, detritivory and carnivory. In the present study, we observed the diet and feeding behaviour of Buccinanops cochlidium from northern Patagonic waters. B. cochlidium fed mainly on living bivalves and, as an opportunistic carrion feeder, on diverse dead animals. It was commonly observed to feed in groups. When one individual of $B$. cochlidium caught a prey, other individuals approached and opportunistically fed on the remains. Juveniles fed exclusively on carrion, including prey recently killed by conspecific adult snails $(39.5 \%$ of the scavenging events). Carrion represented $57.8 \%$ of the B. cochlidium diet on the whole. Predation seemed to be related to the size of $B$. cochlidium individuals, in particular, the foot, which is used to hold and manipulate the prey. We observed no feeding activity for gravid $B$. cochlidium females in the field. In summary, our results show that $B$. cochlidium is a carnivorous species, both as a scavenger and as a predator, that feeds mainly on dead crabs and living bivalves. Adults of $B$. cochlidium predated actively and fed opportunistically on dead animals of larger sizes, whereas hatchlings and juveniles fed exclusively on carrion, including by-products generated by the predation of larger $B$. cochlidium individuals.
\end{abstract}

KEY WORDS: Predation $\cdot$ Carrion $\cdot$ Social foraging $\cdot$ Juveniles $\cdot$ Patagonia

\section{INTRODUCTION}

Feeding strategies have been extensively studied in gastropods, showing a wide variety of nutritional resources, feeding behaviours, and associated anatomical and physiological adaptations (e.g. Graham 1955, Taylor et al. 1980, Taylor \& Miller 1989, Taylor 1996, Kohn et al. 1997, Morton \& Chan 1997, Morton \& Britton 2002, Dietl et al. 2004). Most of the approximately 10000 neogastropod species are carnivorous, including both predators and carrion feeders; these species share a series of radular, pedal musculature and behavioural adaptations (Taylor et al. 1980, Barco et al. 2010). Predation among gastropods comprises a series of complex behaviours, including search, capture, immobilization, penetration of prey and, finally, ingestion (Taylor et al. 1980). This characteristic sequence allows fairly accurate estimation of the frequency of occurrence of prey through direct field observations, without being skewed by the digestion mechanisms of individuals (Hyslop 1980). Although extensive studies have described the diet and feeding strategies of these organisms (e.g. Martel et al. 1986, Morton 2003, Bigatti et al. 2009, Morton 2011), observations of social foraging (including group feeding, resource competition, predatory hazard, facilitation and kleptoparasitism; sensu Giraldeau \& Caraco 2000) are scarce among marine gastropods.

The Nassariidae are generally considered to be carrion feeders (Harasewych 1998), although most of the studies on the diet and feeding aspects of this 
family have been carried out on a single genus, Nassarius. Nevertheless, the feeding habits of this genus also include herbivory, detritivory (Scheltema 1964) and carnivory (Morton \& Britton 2002), including cannibalism (Morton \& Chan 1997). Its radula, broad foot, acute chemoreception and a long extensible proboscis are suited for deposit feeding, but also for opportunistic scavenging (Morton 2011). The intensity of the attraction of scavenging Nassarius spp. to food and their preferences among prey items may depend on the rate of organic matter leaching and the time of decomposition of the prey (Morton \& Jones 2003).

Among species of the nasarriid genus Buccinanops d'Orbigny, 1841, studies regarding feeding are scarce. Some dietary aspects of $B$. monilifer (Kiener, 1834) were recorded by Penchaszadeh (1971); individual stomach contents suggested a diet that included crustaceans and bivalves. No references exist on the diet or food preferences of B. cochlidium (Dillwyn, 1817).

In the present study, we studied the diet and feeding behaviour of Buccinanops cochlidium, with special emphasis on social foraging and differences throughout its life. Particularly, we examined whether $B$. cochlidium is an obligate carrion feeder or also a predator, and whether a difference between juvenile and adult diets exists.

\section{MATERIALS AND METHODS}

Monthly field sampling was performed in Playa Villarino in Golfo San José, Argentina $\left(42^{\circ} 24^{\prime} \mathrm{S}\right.$, $64^{\circ} 27^{\prime} \mathrm{W}$ ) (Fig. 1), over a 36 mo period (December 2004 to November 2007). Sampling was conducted in

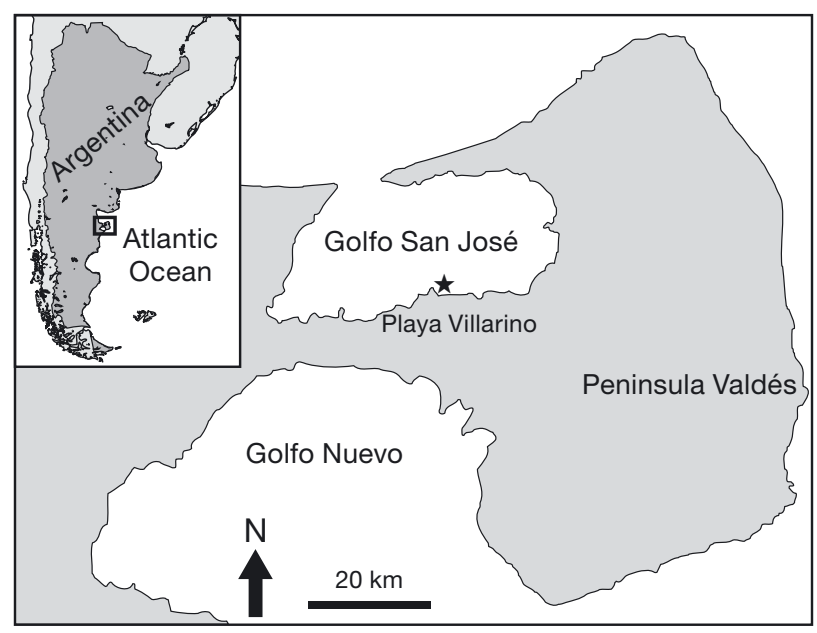

Fig. 1. Sampling location ( $\star)$ daylight by scuba diving at depths of 5 to $15 \mathrm{~m}$. From spring to summer, the sampling effort was higher ( 2 to 3 samples $\mathrm{mo}^{-1}$ ), taking advantage of good weather conditions.

Bottom water temperature varied between $9.2^{\circ} \mathrm{C}$ (September; end of winter) and $18.9^{\circ} \mathrm{C}(\mathrm{March}$; end of summer), recorded in situ with a $\mathrm{HOBO}{ }^{\circledR}$ data logger. The sediments in the study area were mainly fine sandy fractions, with variable mollusc shell fragments.

\section{Diet}

During the sampling period, all individuals of Buccinanops cochlidium found in the area-representing the complete size range - were observed in situ. This accounted for $>100 \mathrm{~h}$ of underwater records (by 2 divers). Whenever they were feeding, the snail and the 'prey' (found either in the process of being hunted, consumed, or already dead) were collected in separate zipper bags for later identification and measurements. 'Prey' items were classified as carrion or prey. In order to differentiate actual prey from carrion, we determined whether the item was in a common or uncommon life position (e.g. an unburied clam), the degree of putrefaction, and whether it was intact or partially/totally consumed. The number of snails around the 'prey' and their behaviour was also recorded.

Authors' previous observations indicated that juvenile snails (approx. $<25 \mathrm{~mm}$ shell length, SL) do not prey actively, but take advantage of carrion. Thus, special attention was given to snail size and whether the food was prey or carrion. We also recorded whether it was a group or solitary event and how many snails were involved. Each feeding event was considered predation if a snail was found to be manipulating, killing, or consuming a living prey.

Additionally, intensive sampling was done in October 2007 and April 2008, to describe Buccinanops cochlidium feeding activity. A sampling area was defined by a $100 \times 50 \mathrm{~m}$ rectangle, between GPS waypoints $42^{\circ} 24^{\prime} 08^{\prime \prime} \mathrm{S}, 64^{\circ} 27^{\prime} 30^{\prime \prime} \mathrm{W}$ and $42^{\circ} 24^{\prime} 10^{\prime \prime} \mathrm{S}$, $64^{\circ} 27^{\prime} 26^{\prime \prime} \mathrm{W}$. A quadrant of $1 \mathrm{~m}^{2}$ was placed around each observed snail, with the individual in the centre. The snail was collected in a zipper plastic bag. Animals found in the quadrant by raking it to a depth of $10 \mathrm{~cm}$ were placed in a separate zipper bag. Whenever the snails were feeding, the 'prey' item was placed in an extra zipper bag.

In the laboratory, all snails were measured for SL from the apex to the tip of the siphonal channel and sexed by the presence/absence of accessory repro- 
ductive glands and organs. Prey were taxonomically identified and measured to their maximum length (ML). All measurements were done using a $0.1 \mathrm{~mm}$ precision calliper.

In addition, the guts of 409 individual snails randomly collected in the monthly sampling were taken to the laboratory and dissected, and stomach content was analyzed under a stereoscopic microscope.

\section{Benthic composition}

The composition of the macro- and mega-faunal community was determined in the study area (epifaunal and infaunal) in October 2007 and April 2008. The presence and abundance of benthic macro- and mega-faunal species were quantified by sampling 10 quadrants of $1 \mathrm{~m}^{2}$, distributed equidistant from each other in 2 transects of $50 \mathrm{~m}$ length parallel to the coastline. The presence and abundance of epifaunal and infaunal organisms were registered in each quadrant. A core $(18 \mathrm{~cm}$ diameter $/ 10 \mathrm{~cm}$ depth) was used to sample infaunal animals. This sample was sucked through a water lifter (WL) device equipped with a collector mesh $(1 \mathrm{~mm})$. All the individuals found at each quadrant (raking $10 \mathrm{~cm}$ in depth) were collected in zipper bags.

All the samples were deposited in separate zipper bags underwater, and fixed in $5 \%$ seawater formalin solution at the surface. Once in the laboratory, the taxon composition and abundance of items in each sample were determined.

\section{RESULTS}

\section{Diet}

During the sampling period 102 Buccinanops cochlidium individuals were recorded feeding in situ. Of these, $59(57.8 \%)$ fed on items classified as carrion, either dead and decayed animals (including e.g. fish by-catch from artisanal fisheries and crabs; $\mathrm{n}=9$ items) or by-products of other events of $B$. cochlidium predation (mainly bivalves and holothurians; $\mathrm{n}=12$ items). The other $43(42.2 \%)$ individuals fed on items classified as prey (living or beginning to be consumed, but without signs of putrefaction or other evidence that could be interpreted as carrion; $\mathrm{n}=43$ items). The total item count was 52, but some of these items were considered prey and carrion, for different snails, at the same time $(\mathrm{n}=12)$, as will be explained later in this section.
All observed juveniles ( $<25 \mathrm{~mm}$ SL) fed on carrion ( $\mathrm{n}=38$ ), including animals killed by adult Buccinanops cochlidium individuals $(31.6 \% ; \mathrm{n}=12)$ and/or other dead animals $(68.4 \%, \mathrm{n}=26)$. Individuals $>25 \mathrm{~mm}$ SL fed on carrion in $32.8 \%$ of the cases $(\mathrm{n}=$ $21)$, including animals killed by other adult $B$. cochlidium $(66.7 \% ; \mathrm{n}=14)$ and/or other dead animals $(33.3 \%, \mathrm{n}=7)$.

Table 1 summarizes the feeding information for Buccinanops cochlidium; distinctions between individual and group feeding events (of prey or carrion) are included. In group events, 1 to 4 adults were commonly accompanied by up to $10 \mathrm{~B}$. cochlidium juveniles that measured between 4 and $25 \mathrm{~mm}$ SL. In 3 cases, juveniles were feeding without adults, all in group events. In 3 cases, juveniles were feeding without adults, all in group events; in these events, most of the prey was consumed, and adults could be seen crawling away from the prey.

The item:snail ratio for living prey was 1:1 (1 Buccinanops cochlidium individual per food item), meanwhile the ratio for items classified as carrion (not counting the items considered prey and carrion at the same time) was 1:3.6 on the whole (up to 1:7 for dead crabs). The group feeding cases in which an adult was observed predating (mainly on bivalves), but there were opportunistic juveniles feeding on the byproducts of the prey (as carrion), corresponded to a rato of 1:1.75 (Table 2).

The living prey were mainly bivalves $(59.8 \%)$, and most were Ensis macha and Tellina petitiana (60.0 and $35.0 \%$ of total bivalve prey, respectively); holothurians of the species Paracaudina chilensis (6.9\%) and echiurids $(1.0 \%)$ were also represented (Table 2).

During the oviposition season, gravid females (carrying egg capsules) were never observed feeding in the field.

Table 1. Buccinanops cochlidium. Feeding events in the field. Number of adult and juvenile snails feeding on prey and carrion items in individual and group events. Carrion includes B. cochlidium snail predation by-products or other carrion

\begin{tabular}{|c|c|c|c|c|c|}
\hline & \multicolumn{3}{|c|}{ No. of snails } & \multicolumn{2}{|c|}{ No. of events } \\
\hline & Total (\%) & Adults & Juv. & Ind. & Group \\
\hline Prey & $43(42.3)$ & 43 & 0 & 33 & 10 \\
\hline Total carrion & $59(57.8)$ & 21 & 38 & 6 & 53 \\
\hline Snail predation & $26(25.5)$ & 14 & 12 & 0 & 27 \\
\hline Other & $33(32.4)$ & 7 & 26 & 6 & 26 \\
\hline Total & $102(100)$ & 64 & 38 & 39 & 63 \\
\hline
\end{tabular}


Table 2. Buccinanops cochlidium. Main taxa in B. cochlidium diet and the number of snails involved per item

\begin{tabular}{lcccc|}
\hline Taxon & Frequency (\%) & Ind. & Items & Ind./item \\
\hline Ensis macha & 42.16 & $43^{\mathrm{a}}$ & 22 & 1.95 \\
Tellina petitiana & 13.73 & 14 & 14 & 1 \\
Aequipecten tehuelchus & 2.94 & $3^{\mathrm{a}}$ & 1 & 3 \\
Ameghinomya antiqua & 0.98 & 1 & 1 & 1 \\
Paracaudina chilensis & 6.86 & $7^{\mathrm{a}}$ & 4 & 1.75 \\
Echiura chilensis & 0.98 & 1 & 1 & 1 \\
Other carrion & 32.35 & 33 & 9 & 3.67 \\
& \\
ataxa may include individuals that are prey and carrion for different snails \\
at the same time
\end{tabular}
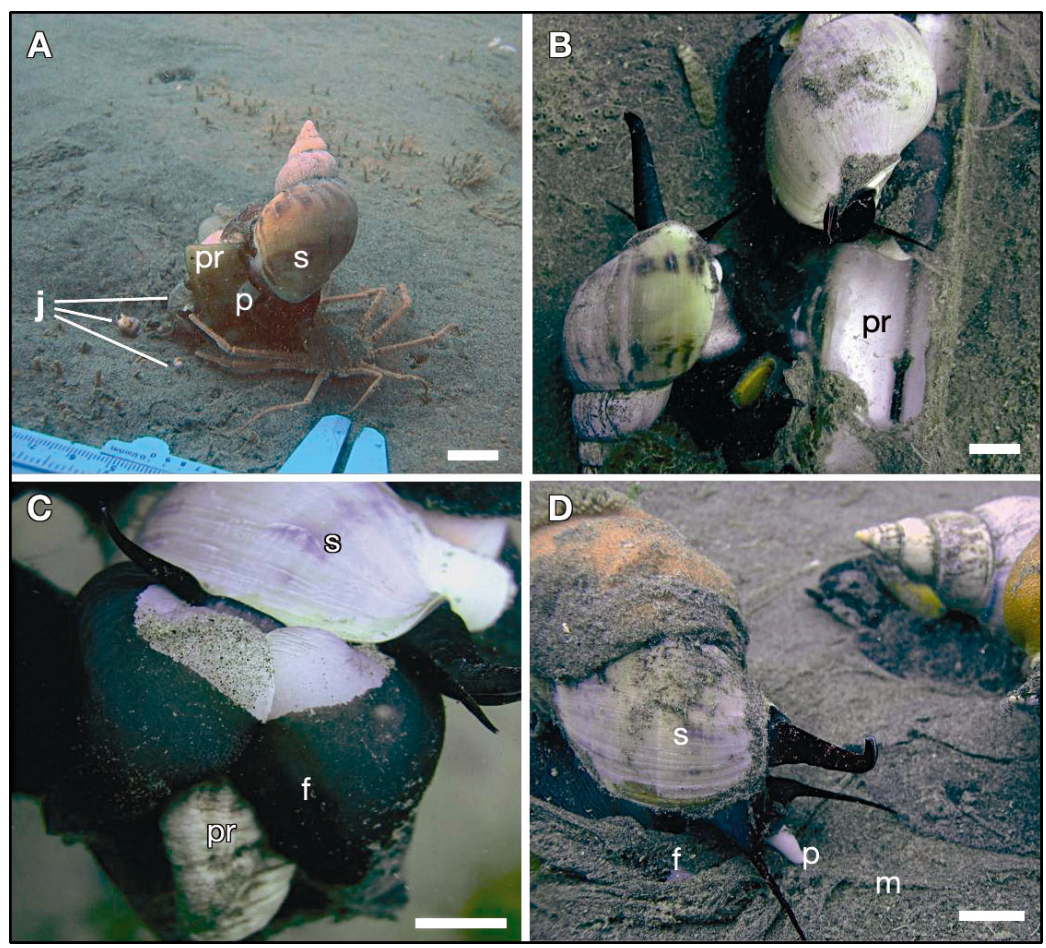

Fig. 2. Buccinanops cochlidium. Snails handling prey and feeding in the field. (A) B. Cochlidium on top of an Ensis macha individual and rasping the siphon with the everted proboscis. Note the small juveniles around the prey. (B) Two individuals of $B$. cochlidium consuming a razor clam. (C) B. cochlidium engulfing a holothuroid (Paracaudina chilensis) with the foot. (D) Individual with everted proboscis ingesting mucus trails of another B. cochlidium. f: foot; j: juveniles; m: mucus; p: proboscis; pr: prey; s: shell. Scale bars $=1 \mathrm{~cm}$ (A to D)

case of holothurian prey, the proboscis penetrated the body wall (Paracaudina chilensis), while in the case of bivalves it was forcefully inserted between the valves (Tellina petitiana, Aequipecten tehuelchus and Ameghinomya antiqua), or it rasped the exposed siphon (Ensis macha).

Some Buccinanops cochlidium ( $\mathrm{n}=$ 2) were observed consuming dead conspecific individuals. It was impossible to determine whether they were killed or eaten as carrion. Occasionally, adult snails were observed crawling on the bottom with an everted proboscis ingesting the mucus trails of other B. cochlidium snails $(\mathrm{n}=2)$ (Fig. 2D); such cases were considered only qualitatively (neither as carrion, nor as predation).

No significant relationship was observed between Buccinanops cochlidium snails and prey size for the 2 more extensively preyed species, the bivalves Ensis macha $(F=4.01$; $\mathrm{p}=$ $\left.0.057 ; \mathrm{r}^{2}=0.149 ; \mathrm{n}=25\right)$ and Tellina petitiana $\left(F=0.53 ; \mathrm{p}=0.489 ; \mathrm{r}^{2}=\right.$ $0.071 ; \mathrm{n}=9$ ).

Of 409 studied stomachs, over $99 \%$ were empty; in 3 cases $(0.73 \%)$, the stomach had muscular tissue (resembling bivalve or other mollusc pedal/ adductor muscle).

\section{Benthic composition}

The benthic community associated with Buccinanops cochlidium consisted of $36 \%$ polychaetes, $41.5 \%$ gastropod molluscs, $8.9 \%$ bivalves, $10.4 \%$ crustaceans and $0 \%$ holothurians when sampled with the water lift (WL). By raking the sediments, we found $0 \%$ polychaetes, $2.7 \%$ gastropods, $3.8 \%$ bivalves, $82.5 \%$ crus-

\section{Prey handling}

During predatory events, Buccinanops cochlidium held the prey with its muscular foot (Fig. 2B) while buried or semi-buried beneath the sediment (Fig. 2C) and consumed the soft parts of the prey with the proboscis by raking it with the radula (Fig. 2A). In the taceans and $1.6 \%$ holothurians in the community. Other groups occasionally present in the sediment (by raking) were the ophurid Ophioplocus januari, echinoid Arbacia dufresnii, squid Loligo sp. spawn, octopus Octopus tehuelchus, chiton Chaetopleura isabellei, ascidia Ciona intestinalis and anemone Antholoba achates, but they were not represented in 
the diet or in WL sampling. Table 3 illustrates the composition of the benthic community, using 2 different sampling methods (WL and raking), and the prevalence of different components in the diet of $B$. cochlidium.

Some common 'prey' items were not represented or were underestimated by the sampling methods, mainly the bivalves Ensis macha (razor clam) and Tellina petitiana, the crabs Leurocyclus tuberculosus and Peltarion spinosulum and the holothurian Para- caudina chilensis (Fig. 2). On the other hand, a large number of species present in the field were not consumed by Buccinanops cochlidium, regardless of their abundance (Table 3).

The anemone Antholoba achates (typically inhabiting hard substrates) was seen abundantly, always attached to the shells of living Buccinanops cochlidium specimens $(46 \%$ of the $B$. cochlidium individuals $>35 \mathrm{~mm}$ SL were colonized by an anemone), as a unique substratum in the area.
Table 3. Abundance (ind. $\mathrm{m}^{-3}$, expressed as \% of total abundance) of the main taxa in the benthos and in the diet of Buccinanops cochlidium. Prevalence in the diet is based on data for the entire sampling period. Sampling was done with either a water lifter (WL) or by raking to $10 \mathrm{~cm}$ depth

\begin{tabular}{|c|c|c|c|}
\hline \multirow[t]{2}{*}{ Taxon } & \multicolumn{2}{|c|}{ Abundance (\%) } & \multirow{2}{*}{$\begin{array}{l}\text { Prevalence } \\
\text { in diet (\%) }\end{array}$} \\
\hline & WL & Raking & \\
\hline Polychaeta $^{a}$ & 36 & 0 & 0 \\
\hline \multicolumn{4}{|l|}{ Gastropoda } \\
\hline Olivella plata & 30.27 & 0 & 0 \\
\hline Buccinanops cochlidium & 0.6 & 0 & 1.96 \\
\hline Ancilla dimidiata & 0.49 & 0 & 0 \\
\hline Epitonium georgiteanum & 7.44 & 0 & 0 \\
\hline Tegula patagonica & 1.98 & 1.63 & 0 \\
\hline Calyptraea pileus & 0.25 & 0 & 0 \\
\hline Odontocymbiola magellanica & 0.49 & 0.54 & 0 \\
\hline Crepidula sp. & 0 & 0.54 & 0 \\
\hline \multicolumn{4}{|l|}{ Bivalvia } \\
\hline Tellina petitiana & 2.49 & 1.63 & 13.73 \\
\hline Pitar rostratus & 1.24 & 0 & 0 \\
\hline Mytilus edulis & 0.28 & 0.54 & 0 \\
\hline Thracia similis & 0.49 & 0 & 0 \\
\hline Panopea abbreviata & 0.24 & 0 & 0 \\
\hline Ameghinomya antiqua & 0.99 & 0 & 0.98 \\
\hline Ensis macha & 0 & 1.09 & 42.16 \\
\hline Mactra sp. & 2.72 & 0 & 0 \\
\hline Tivella sp. & 0.49 & 0 & 0 \\
\hline Aequipecten tehuelchus & 0 & 0.54 & 2.94 \\
\hline \multicolumn{4}{|l|}{ Crustacea } \\
\hline Peltarion spinosulum & 0.49 & 26.77 & 20.59 \\
\hline Leurocyclus tuberculosus & 0.49 & 52.46 & 6.86 \\
\hline Ovalipes trimaculatus & 0 & 0 & 0.98 \\
\hline Rochinia gracilipes & 0.74 & 1.63 & 0 \\
\hline Cyrtograpsus affinis & 0.24 & 0 & 0 \\
\hline Serolis schythei & 0.24 & 1.63 & 0 \\
\hline Balanus sp. & 1.98 & 0 & 0 \\
\hline Tanaidacea & 3.22 & 0 & 0 \\
\hline Myscidacea & 1.98 & 0 & 0 \\
\hline Leptostraca & 0.99 & 0 & 0 \\
\hline \multicolumn{4}{|l|}{ Holothuroidea } \\
\hline Paracaudina chilensis & 0 & 1.63 & 6.86 \\
\hline \multicolumn{4}{|l|}{ Echiurida } \\
\hline Echiura chilensis & 0 & 0 & 0.98 \\
\hline \multicolumn{4}{|l|}{ Other carrion } \\
\hline Dead fishes / fish spawn & 0 & 0 & 1.96 \\
\hline
\end{tabular}

\section{DISCUSSION}

Buccinanops cochlidium feeds as an opportunistic carrion feeder on diverse dead animals (mostly crabs or other invertebrates and fishes/fish spawns), but also predates, mainly on bivalve molluscs. During this study, it was commonly observed to feed in groups.

Buccinanops cochlidium fed on both carrion and living prey. Adult individuals (>25 mm SL) predated actively on living invertebrates, mainly bivalves. Carrion feeding in adult $B$. cochlidium snails represented up to $32.8 \%$ of overall feeding, while juveniles ( $<25 \mathrm{~mm} \mathrm{SL}$ ) fed exclusively on carrion. These carrion items originated from the remains of adult predation in $31.6 \%$ of the cases of juvenile feeding, and in $44.1 \%$ of the cases of overall carrion feeding (adults and juveniles). Carrion represented $57.8 \%$ of the observed snail diet on the whole, of which $27.8 \%$ stemmed from carrion facilitated by adults for juveniles. These results reflect the fact that predatory adult byproducts increased the availability of food, which was opportunistically capitalized on by other adults and, especially, by juveniles.

As reviewed by Giraldeau \& Caraco (2000), predators obtain food as solitary foragers, while carrion feeders opportunistically feed on dead animals. In both cases, social foragers (animals involved in group feeding events) can invest time and energy in finding their own food or avoid some 
costs of the search-capture-ingestion cycle by exploiting food that other foragers' efforts have made available. Social foraging appears to illustrate the economic interdependence of individuals as far as payoffs and penalties are concerned, including cooperative or non-cooperative solutions, parented or non-parented individuals, and even social or nonsocial organisms (Giraldeau \& Caraco 2000). In this context, feeding interactions among Buccinanops cochlidium individuals might be considered a tradeoff between predatory and opportunistic behaviour. In particular, juveniles of $B$. cochlidium, which apparently depend on the availability of carrion to survive, would probably feed opportunistically on larger individual prey. A negative interaction, such as the scramble kleptoparasitism of juveniles on adults or the positive interaction of facilitation of juveniles by adults (Giraldeau \& Caraco 2000, de Goeij et al. 2001, Laguë et al. 2012), should, however, not be discounted.

The ontogeny of predators is commonly marked by a succession of niche shifts and trophic level changes involving progressively larger prey (Werner \& Gilliam 1984, Olson \& Mittelbach 1995). Alternatively, handling time, energy intake budget and predation risk are of the most relevant parameters influencing the switch in prey species and/or size (Serra et al. 1997); this is mostly related to changes in the predator's body size and radular teeth (Duda et al. 2009). Predation behaviour seemed to be related to individual size in Buccinanops cochlidium, in particular the large muscular foot used by large individuals to hold and manipulate prey. To the authors' knowledge, this is the first report on social foraging, together with ontogenic switching in the diet, of nassariid gastropods. This could be related to the considerable reproductive investment, with long parental care prior to hatching, made by this species (Averbuj \& Penchaszadeh 2010). In any case, these conjectures need far more research and data including studies of filiation and other experimental approaches.

The snails:item ratio showed that carrion items presented a larger number of Buccinanops cochlidium individuals (ratio $=3.67$ ) than predation items, which may be eaten by a unique predator (ratio $=1$ ) or the predator and some other individuals attracted by the new carrion resource (ratio $=1.75$ to 3 ) (Table 2 ).

Throughout the sampling period (diurnal dives), these snails showed high general activity, including crawling, mating, escaping from predators, feeding and spawning. A few nocturnal dives showed that the general activities of the snails were similar to those in daylight, but no feeding events were ob- served. The observations made in this study showed that large-sized Buccinanops cochlidium ( $>25 \mathrm{~mm}$ in SL) hold the whole prey (Tellina petitiana or Paracaudina chilensis) or part of it (in larger prey such as Ensis macha) with their foot. Then, the proboscis is used to penetrate the prey and rasp the flesh with the radula. When predating on living bivalves, $B$. cochlidium inserts its proboscis between the valve edges, or directly into the soft bodies when possible (as in E. macha), and never bores through them. There is a unique record of shell boring in nassariids by mechanical rasping and chemical dissolution (Morton \& Chan 1997), but this has never been reported for Buccinanops species. Smaller juveniles approach dead animals and rasp the exposed flesh by means of their radula. The size limitations of its foot (used to hold prey) and proboscis (penetration) are probably related to mandatory feeding on carrion by smaller $B$. cochlidum individuals (Duda et al. 2009). B. cochlidium is exclusively carnivorous, even though several snails had macroalgae (Ulva sp. and Dictyota sp.) growing on their shells, snails were not seen feeding on it (and algae were not cropped), as reported for other Nassariidae (Scheltema 1964, Harris et al. 1986). Furthermore, some buried adult individuals $(n=8)$ were found with their proboscis elongated in the sediment, which may correspond to feeding events on microscopic organisms (Taylor et al. 1980, Morton 2011) or on a small individual of its common diet (such as Tellina petitiana) that escaped our observation. The 2 cases of cannibalism were probably actually carrion feeding on conspecific individuals. The stomach content analyses did not provide any results in $99 \%$ of the cases, probably due to the delay between capture in the field and fixation on land. We observed no regurgitation.

The availability of prey in the samples from Playa Villarino was dominated by small species and juveniles of larger species. The WL sampling methodology represents the macro-infauna well, while megainfauna and macro- and mega-epifauna are scarcely represented. These under-represented taxa include the large bivalves Ensis macha (relevant in Buccinanops cochlidium diet), which buried rapidly, and crabs that crawled off the quadrant quickly. Other species may be so sparsely represented that a higher sampling effort would be required to record their presence (e.g. holothurians and echiurids). Complementarily, the raking methodology represented mega-epifauna and -infauna, but underestimated macro-fauna.

Gastropod molluscs and polychaetes were the most abundant groups represented in the WL samples, 
although they were not present in the Buccinanops cochlidium diet, while crabs were almost exclusively represented in the raking sampling (mostly carrion feeding). Among bivalves represented in the benthic samples, species that are included in the diet (mainly predation) were underestimated in respect to others not consumed. This suggests a sort of prey selectivity that might be related to the accessibility of organisms to $B$. cochlidium predation (e.g. the soft bodies of Ensis macha or the easy-opening valves of Tellina petitiana), although this assumption should be confirmed by further studies. Some species present in the samples that were not predated were ingested as carrion when found dead (crabs) or recently predated upon by other organisms (fishes, fish spawns).

In summary, according to our results, Buccinanops cochlidium should be considered a carnivorous species that feeds on carrion and primarily predates living bivalves. Opportunistically, adult individuals also took advantage of prey hunted by other adults; juveniles fed exclusively on carrion. Size could be the limiting factor for the switch from mandatory carrion to facultative carrion/predator feeders. This might be related to a minimum size needed to handle prey, or a negative relationship between size and energy cost of handling/consuming a prey (Paine 1966). Furthermore, social foraging (feeding in groups) may benefit the food-provisioning of other individuals (particularly juveniles that do not predate) and represent a trade-off for adults between active predation and opportunistic scavenging (Giraldeau \& Caraco 2000, Laguë et al. 2012). This is the first extensive report on the diet and feeding behaviour of $B$. cochlidium.

Acknowledgements. This research was partially supported by the projects PICTR-01869, PIP 051 and PIP 0732. We thank the many people who helped with field work, in particular S. Zabala and C. Sanchez Antelo for field and laboratory assistance. S. Quiroga, D. Lauretta and M. Martinez helped with the identification of benthic samples. J. P. Livore, G. Bigatti and G. Herbert made early suggestions that greatly improved this manuscript. The field work was conducted in a Protected Natural Area of Chubut Province, with permits from the Secretaría de Turismo y Areas Protegidas. The authors are members of CONICET. All research work, including sampling and laboratory research, comply with current Argentine laws.

\section{LITERATURE CITED}

> Averbuj A, Penchaszadeh PE (2010) Reproductive seasonality, oviposition and development of the nassariid whelk Buccinanops cochlidium (Dillwyn, 1817) in Patagonia, Argentina. J Molluscan Stud 76:25-32

> Barco A, Claremont M, Reid DG, Houart R and others (2010) A molecular phylogenetic framework for the Muricidae, a diverse family of carnivorous gastropods. Mol Phylogenet Evol 56:1025-1039

Bigatti G, Sánchez Antelo CJM, Miloslavich P, Penchaszadeh PE (2009) Feeding behavior of Adelomelon ancilla: a predator neogastropod in Patagonian benthic communities. Nautilus 123:159-165

de Goeij P, Luttikhuizen PC, van der Meer J, Piersma T (2001) Facilitation on an intertidal mudflat: the effect of siphon nipping by flatfish on burying depth of the bivalve Macoma balthica. Oecologia 126:500-506

Dietl GP, Herbert GS, Vermeij GJ (2004) Reduced competition and altered feeding behavior among marine snails after a mass extinction. Science 306:2229-2231

> Duda TF, Kohn AJ, Matheny AM (2009) Cryptic species differentiated in Conus ebraeus, a widespread tropical marine gastropod. Biol Bull 217:292-305

Graham A (1955) Molluscan diets. Proc Malacol Soc Lond 31:144-159

Giraldeau LA, Caraco T (2000) Social foraging theory. Princeton University Press, Princeton, NJ

Harasewych MG (1998) Family Nassariidae. In: Beesley PL, Ross GJB, Wells A (eds) Mollusca: the southern synthesis. Fauna of Australia, CSIRO Publishing, Melbourne, p 829-831

Harris SA, da Silva FM, Bolton JJ, Brown AC (1986) Algal gardens and herbivory in a scavenging sandy-beach nassariid whelk. Malacologia 27:299-305

> Hyslop EJ (1980) Stomach contents analysis - a review of methods and their application. J Fish Biol 17:411-429

Kohn A, Taylor JD, Wai JM (1997) Diets of predatory gastropods of the families Mitridae and Buccinidae in the Houtman Abrolhos Islands, Western Australia. In: Wells FE (ed) The marine flora and fauna of the Houtman Abrolhos Islands, Western Australia. Western Australian Museum, Perth, p 133-139

Laguë M, Tania N, Heath J, Edelstein-Keshet L (2012) The effects of facilitation and competition on group foraging in patches. J Theor Biol 310:88-96

Martel A, Larrivée DH, Himmelman JH (1986) Behaviour and timing of copulation and egg-laying in the neogastropod Buccinum undatum L. J Exp Mar Biol Ecol 96: $27-42$

> Morton B (2003) Observations on the feeding behaviour of Nassarius clarus (Gastropoda: Nassariidae) in Shark Bay, Western Australia. Molluscan Res 23:239-249

Morton B (2011) Behaviour of Nassarius bicallosus (Caenogastropoda) on a northwestern Western Australian surf beach with a review of feeding in the Nassariidae. Molluscan Res 31:90-94

> Morton B, Britton JC (2002) Holothurian feeding by Nassarius dorsatus on a beach in Western Australia. J Molluscan Stud 68:187-189

> Morton B, Chan K (1997) First report of shell boring predation by a member of the Nassariidae (Gastropoda). J Molluscan Stud 63:476-478

> Morton B, Jones DS (2003) The dietary preferences of a suite of carrion-scavenging gastropods (Nassariidae, Buccinidae) in Princess Royal Harbour, Albany, Western Australia. J Molluscan Stud 69:151-156

> Olson MH, Mittelbach G (1995) Competition between predator and prey: resource-based mechanisms and implications for stage-structured dynamics. Ecology 76: 1758-1771

Paine RT (1966) Function of labial spines, composition of diet, and size of certain marine gastropods. Veliger 9:17-24 
Penchaszadeh PE (1971) Observaciones sobre la reproducción y ecología de Dorsanum moniliferum (Valenciennes, 1834) (Gastropoda: Buccinidae) en la región de Mar del Plata. Neotropica 17:49-54

Scheltema RS (1964) Feeding habits and growth in the mudsnail Nassarius obsoletus. Chesap Sci 5:161-166

Serra G, Chelazzi G, Castilla JC (1997) Effects of experience and risk of predation on the foraging behaviour of the south-eastern Pacific muricid Concholepas concholepas (Mollusca: Gastropoda). J Anim Ecol 66: 876-883

Editorial responsibility: Riccardo Cattaneo-Vietti, Genova, Italy
Taylor JD (1996) Origin and evolutionary radiation of the mollusca. Oxford University Press, London

Taylor JD, Miller JA (1989) The morphology of the osphradium in relation to feeding habits in meso- and neogastropods. J Molluscan Stud 55:227-237

Taylor JD, Morris NJ, Taylor CN (1980) Food specialization and the evolution of predatory prosobranch gastropods. Palaeontology 23:375-409

Werner EE, Gilliam JF (1984) The ontogenetic niche and species interactions in size-structured populations. Annu Rev Ecol Syst 15:393-426

Submitted: May 30, 2012; Accepted: October 15, 2012

Proofs received from author(s): December 6, 2012 